DOI: 10.52362/jmijayakarta.v1i2.447

\title{
SISTEM INFORMASI PENJUALAN DAN PENGENDALIAN STOCK BARANG BANGUNAN PADA TOKO BANGUNAN DELIMA
}

\author{
Maulana Mustopa ${ }^{1}$, Ifan Junaedi ${ }^{2}$, Anton Zulkarnain Sianipar ${ }^{3}$ \\ Program Studi Sistem Informasi ${ }^{1}$, Program Studi Teknik Informatika ${ }^{2}$, \\ Program Studi Teknik Sistem Informasi ${ }^{3}$ \\ Sekolah Tinggi Manajemen Informatika dan Komputer Jayakarta \\ e-mail: maulanamustopa16564006@gmail.com ${ }^{1}$, ifanjunaedi8@gmail.com ${ }^{2}$, \\ antonz.jayakarta@gmail.com ${ }^{N}$
}

\begin{abstract}
Abstrak
Sistem penjualan digital sekarang ini sudah banyak dimanfaatkan oleh usaha kecil maupun menengah sehingga dapat mempermudah pelanggan dalam pemesanan barang terlebih lagi internet menjadi gaya hidup sebagian besar masyarakat yang ingin semuanya serba praktis dan cepat. Toko Bangunan Delima adalah sebuah toko bangunan yang sedang berkembang dan bergerak dalam bidang penjualan material bangunan,dimana pengolahan data barangnya masih dilakukan secara manual dan seluruh laporan kegiatan sistem pembukuannya masih kurang tersetruktur. Kendala yang muncul yaitu masalah waktu dimana dalam melakukan pembukuan atau pengecekkan data barang terlalu lama dan juga masalah pengontrolan stok barang yang tersedia kurang begitu teratur secara baik. Oleh karena itu penulis merancang Sistem Informasi Penjualan Dan Pengendalian Stock Barang Material Bangunan berbasis web menggunakan Php Mysql,Xampp dan Framework Laravel. Sumber data yang diperoleh yaitu melalui sumber data primer dan teknik pengumpulan datanya dilakukan dengan cara observasi,wawancara dan dokumentasi. Diharapkan sistem ini dapat mempermudah toko Delima dalam menjalankan bisnisnya serta meraih keuntungan ditengah banyak persaingan.
\end{abstract}

Kata kunci: Sistem, Informasi, UML

Abstract: Digital sales system is now widely utilized by small and medium businesses so as to facilitate customers in ordering goods moreover the internet becomes the lifestyle of most people who want everything to be practical and fast. Pomegranate Building Shop is a building shop that is developing and engaged in the sale of building materials, where the processing of goods data is still done manually and the entire report of the bookkeeping system activities are still under construction. The obstacles that arise are the problem of time in which in doing bookkeeping or checking the goods data for too long and also the problem of controlling the stock of goods available is less so regularly in a good manner. Therefore the author designed the Web-based Building Materials Stock Information And Control System using the Php Mysql,Xampp and Laravel Framework. The data source obtained is through the primary data source and the data collection technique is done by observation, interview and documentation. It is expected that this system can facilitate pomegranate stores in running their business and gain profits amid a lot of competition.

Keywords: System, Information, UML.

\section{PENDAHULUAN}

Toko Bangunan Delima adalah sebuah toko bangunan yang sedang berkembang dan bergerak dalam bidang penjualan material bangunan. Berdasarkan hasil wawancara dengan pihak toko, maka didapat informasi tentang pengolahan data barang yang masih dilakukan secara manual dan seluruh 
DOI: 10.52362/jmijayakarta.v1i2.447

laporan kegiatan sistem pembukuannya masih kurang tersetruktur. Kendala yang muncul dengan menggunakan sistem yang manual yaitu masalah waktu dimana dalam melakukan pembukuan atau pengecekkan data barang terlalu lama dan juga masalah pengontrolan stok barang yang tersedia kurang begitu teratur secara baik.

Masalah-masalah tersebut di atas mengharuskan pihak toko untuk menerapkan sistem informasi penjualan dan pengendalian stok barang material yang mampu memproses data secara cepat, akurat dan secara otomatis mampu menyimpan serta menampilkan data transaksi.

Dari masalah yang dijabarkan di atas maka penelitian ini bertujuan untuk merancang "Sistem Informasi Penjualan dan Pengendalian Stok Barang pada Toko Bangunan Delima Berbasi WEB" yang diharapkan dapat memenuhi kebutuhan dan bisa memudahkan Toko Bangunan dalam menjalankan kegiatan bisnis seperti melakukan pengendalian stok barang, melakukan penjualan, membuat laporan dan melakukan transaksi secara terkomputerisasi.

\section{Pengertian Penjualan}

Penjualan merupakan pembelian sesuatu (barang atau jasa) dari suatu pihak kepada pihak lainnya dengan mendapatkan ganti uang dari pihak tersebut. Penjualan juga merupakan suatu sumber pendapatan perusahaan, semakin besar penjualan maka semakin besar pula pendapatan yang diperoleh perusahaan.

Penjualan (sales) adalah aktivitas atau bisnis dalam menjual produk atau jasa. Aktivitas penjualan adalah hal yang sangat penting bagi perusahaan, terutama untuk meraih keuntungan. Pengertian penjualan secara umum adalah kegiatan jual beli dijalankan oleh dua belah pihak atau lebih dengan alat pembayaran yang sah.

Penjualan ini dapat dilakukan dengan berbagai metode, seperti penjualan langsung serta agen penjualan. Tujuan utama penjualan adalah mendatangkan keuntungan dari produk atau barang yang dijual. Dalam pelaksanaannya, penjualan tidak dapat dilakukan tanpa adanya kontribusi dari pelaku yang bekerja, seperti pedagang, agen, dan tenaga pemasaran. (Anik Sri Wahyuningsih, 2017).

\section{Penjualan Konvensional}

Penjualan atau pemasaran Konvensional adalah salah satu jenis pemasaran yang dilakukan secara langsung (bukan online) dengan metode-metode konvensional (menggunakan kebiasaan umum yang lazim digunakan). Pembeli mendatangi langsung calon penjual secara bertatap muka dan begitu pula sebaliknya.

Sehingga, bisa diambil kesimpulan bahwa pemasaran konvensional merupakan proses untuk mengkomunikasikan tawaran atau produk kepada calon pelanggan secara langsung (offline) dengan menggunakan cara normal yang biasa dilakukan

\section{Penjualan Digital}

Penjualan digital adalah pemasaran produk atau layanan dengan menggunakan teknologi digital melalui internet, media sosial, telepon seluler, atau media digital lainnya.

Ini juga merupakan istilah umum yang mencakup berbagai strategi pemasaran seperti Pemasaran Media Sosial, Pengoptimalan Mesin Telusur (SEO), dan Pemasaran Email.

Dibandingkan dengan metode pemasaran tradisional seperti media cetak, papan reklame, dan $\mathrm{TV}$, pemasaran digital pada dasarnya didorong oleh data. Banyak platform periklanan digital populer saat ini menyediakan akses ke laporan kampanye untuk analisis data yang komprehensif.

Dengan kekuatan gabungan dari internet dan teknologi, Pemasar Digital saat ini dapat mengumpulkan dan menganalisis data dari perilaku pelanggan yang berbeda atau keterlibatan pengguna, memungkinkan mereka untuk memfasilitasi konten dan iklan yang lebih dipersonalisasi ke arah audiens yang ditentukan dengan jelas untuk keterlibatan dan hasil yang lebih baik. 


\section{TINJAUAN LITERATUR}

DOI: 10.52362/jmijayakarta.v1i2.447

Seperti telah diketahui bersama bahwa dewasa ini telah banyak para ahli mendefinisikan mengenai sistem. Beberapa pengertian sistem yang diambil dalam penelitian kali ini adalah pengertian yang diberikan oleh Sutabri. Sutabri memberikan pengertian sistem sebagai sekelompok unsur-unsur yang erat hubungannya satu dengan yang lain, yang berfungsi bersama-sama untuk mencapai tujuan tertentu (Sutabri, 2012). Dalam arti yang lain, sistem didefinisikan sebagai suatu kumpulan atau himpunan dari unsur, komponen, atau variabel yang terorganisir, saling interaksi, saling tergantung satu sama lain, dan terpadu (Mudjahidin \& Putra, 2010). Pada intinya, sebuah sistem adalah sekumpulan entitas (hardware, brainware, software) yang saling berinteraksi, bekerjasama dan berkolaborasi untuk mencapai tujuan tertentu.

\section{Pengertian Sistem Informasi}

Sistem informasi terdiri dari komponen-komponen yang disebut blok bangunan (Building Block), yang terdiri dari blok masukan, blok model, blok keluaran, blok teknologi, blok basis data, dan blok kendali. Sebagai suatu sistem, keenam blok bangunan tersebut masing-masing saling berinteraksi satu dengan yang lain membentuk suatu kesatuan untuk mencapai sasaran. Blok bangunan itu terdiri dari:

1. Blok Masukan (Input Block)

Input mewakili data yang masuk ke dalam sistem informasi. Input yang dimaksud adalah metode dan media untuk menangkap data yang akan dimasukan, yang dapat berupa dokumen-dokumen dasar.

2. Blok Model (Model Block)

Blok ini terdiri dari kombinasi prosedur, logika dan model matematik yang akan memanipulasi data input dan data yang tersimpan di basis data dengan cara yang sudah tertentu untuk menghasilkan keluaran yang diinginkan.

3. Blok Keluaran (Output Block)

Produk dari sistem informasi adalah keluaran yang merupakan informasi yang berkualitas dan dokumentasi yang berguna untuk semua tingkatan manajemen serta semua pemakai sistem.

4. Blok Teknologi (Technology Block)

Teknologi merupakan tool box dalam sistem informasi. Teknologi digunakan untuk menerima input, menjalankan model, menyimpan dan mengakses data, menghasilkan dan mengirimkan keluaran dan membantu pengendalian system.

\section{Pengertian Penjualan}

Penjualan merupakan pembelian sesuatu (barang atau jasa) dari suatu pihak kepada pihak lainnya dengan mendapatkan ganti uang dari pihak tersebut. Penjualan juga merupakan suatu sumber pendapatan perusahaan, semakin besar penjualan maka semakin besar pula pendapatan yang diperoleh perusahaan.

Penjualan (sales) adalah aktivitas atau bisnis dalam menjual produk atau jasa. Aktivitas penjualan adalah hal yang sangat penting bagi perusahaan, terutama untuk meraih keuntungan. Pengertian penjualan secara umum adalah kegiatan jual beli dijalankan oleh dua belah pihak atau lebih dengan alat pembayaran yang sah.

Penjualan ini dapat dilakukan dengan berbagai metode, seperti penjualan langsung serta agen penjualan. Tujuan utama penjualan adalah mendatangkan keuntungan dari produk atau barang yang dijual. Dalam pelaksanaannya, penjualan tidak dapat dilakukan tanpa adanya kontribusi dari pelaku yang bekerja, seperti pedagang, agen, dan tenaga pemasaran. (Anik Sri Wahyuningsih, 2017).

\section{Penjualan Konvensional}

Penjualan atau pemasaran Konvensional adalah salah satu jenis pemasaran yang dilakukan secara langsung (bukan online) dengan metode-metode konvensional (menggunakan kebiasaan 
DOI: 10.52362/jmijayakarta.v1i2.447

umum yang lazim digunakan). Pembeli mendatangi langsung calon penjual secara bertatap muka dan begitu pula sebaliknya.

Jika ditilik secara bahasa, 'pemasaran konvensional' terdiri dari dua kata dasar yakni 'pemasaran' dan 'konvensional'. Pemasaran (dalam bahasa Inggris: 'Marketing') berarti serangkaian aktivitas atau proses untuk mengkomunikasikan tawaran atau produk kepada calon pelanggan. Sementara konvensional adalah suatu cara yang dilakukan dengan mengikuti cara normal atau hal-hal yang biasa dilakukan pada khalayak umum dari masa ke masa.

Sehingga, bisa diambil kesimpulan bahwa pemasaran konvensional merupakan proses untuk mengkomunikasikan tawaran atau produk kepada calon pelanggan secara langsung (offline) dengan menggunakan cara normal yang biasa dilakukan

\section{Penjualan Digital}

Penjualan digital adalah pemasaran produk atau layanan dengan menggunakan teknologi digital melalui Internet, Media sosial, Telepon Seluler, atau media digital lainnya.

Ini juga merupakan istilah umum yang mencakup berbagai strategi pemasaran seperti Pemasaran Media Sosial, Pengoptimalan Mesin Telusur (SEO), dan Pemasaran Email.

Dibandingkan dengan metode pemasaran tradisional seperti media cetak, papan reklame, dan $\mathrm{TV}$, pemasaran digital pada dasarnya didorong oleh data. Banyak platform periklanan digital populer saat ini menyediakan akses ke laporan kampanye untuk analisis data yang komprehensif.

Dengan kekuatan gabungan dari internet dan teknologi, Pemasar Digital saat ini dapat mengumpulkan dan menganalisis data dari perilaku pelanggan yang berbeda atau keterlibatan pengguna, memungkinkan mereka untuk memfasilitasi konten dan iklan yang lebih dipersonalisasi ke arah audiens yang ditentukan dengan jelas untuk keterlibatan dan hasil yang lebih baik.

\section{METODE PENELITIAN}

Metode yang digunakan dalam melaksanakan penelitian merupakan dasar penyusunan rancangan penelitian dan merupakan penjabaran dari metode ilmiah secara umum dimana metode penelitian dijelaskan dari awal perencanan hingga tercapainya tujuan penelitian.

Jenis metode penelitian yang penulis gunakan dalam penelitian ini adalah menggunakan metode kualitatif yang bersifat deskriptif pada pendekatan kasus di Toko Bangunan Delima, yaitu suatu metode yang pada tahap pertama penulis melakukan dengan cara mengumpulkan data dan bahan yang diperlukan terlebih dahulu, dan pada tahap berikutnya penulis mengolah dan membahas sampai pada suatu kesimpulan yang pada akhirnya dapat dibuat suatu laporan untuk melampirkan semua kegiatan yang dikerjakan selama dilakukannya penelitian di Toko Bangunan Delima.

\section{Metode Waterfall}

Model air terjun, terkadang disebut siklus hidup klasik, menunjukkan pendekatan, sistematis sekuensial untuk pengembangan perangkat lunak yang dimulai dengan pelanggan menspesifikasi persyaratan yang diinginkan dan berlangsung melalui perencanaan, pemodelan, konstruksi, dan penyebaran, yang berpuncak pada dukungan yang berkelanjutan dari perangkat lunak yang telah selesai. Tahapan dari Waterfall Model merefleksikan pokok-pokok dari aktivitas pengembangan :

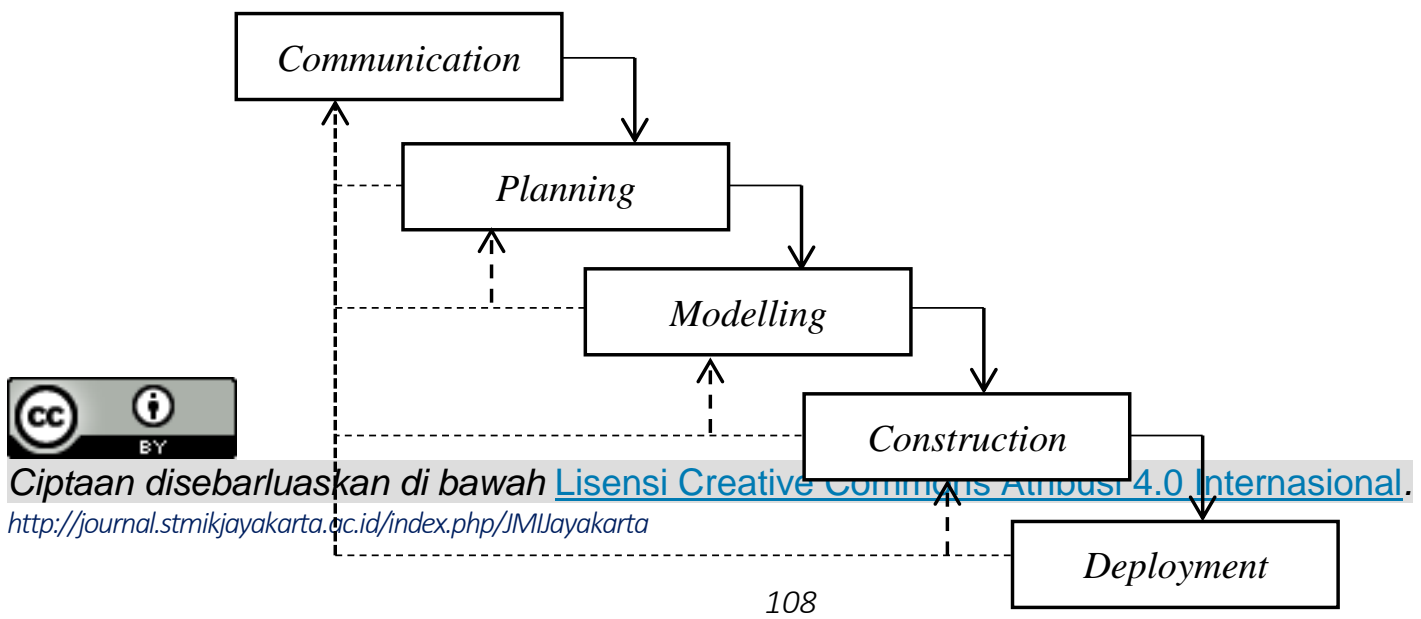


DOI: 10.52362/jmijayakarta.v1i2.447

\section{Perancangan}

Tahapan perancangan adalah proses desain sistem, yaitu proses perencanaan dan pemecahan masalah untuk solusi perangkat lunak.Pada tahapan desain sistem ini ada beberapa rancangan yang dibuat agar sistem dapat dibuat, yaitu usecase diagram, activity diagram dan ER Diagram.

\subsection{Usecase diagram}

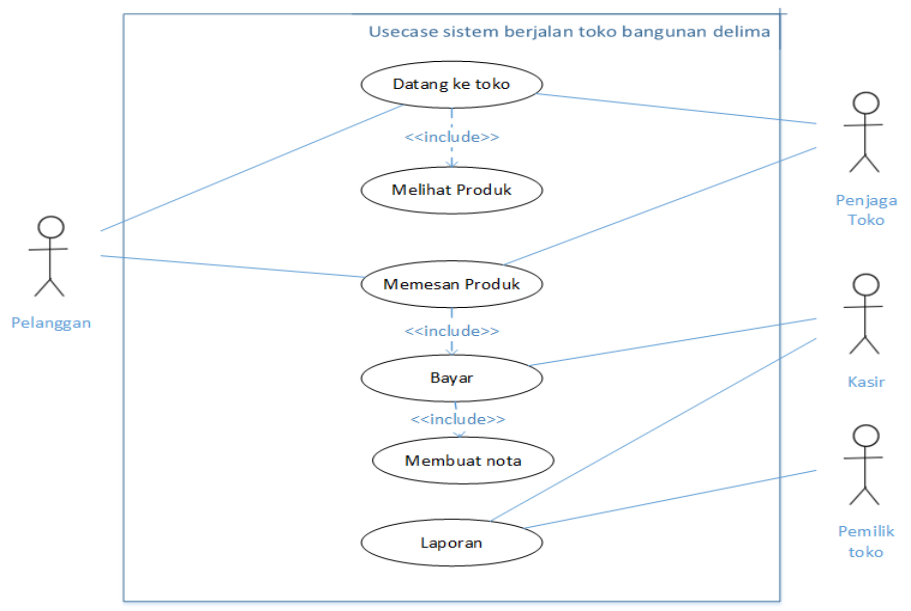

Gambar 3. 2 Usecase Diagram

\subsection{Activity Diagram}




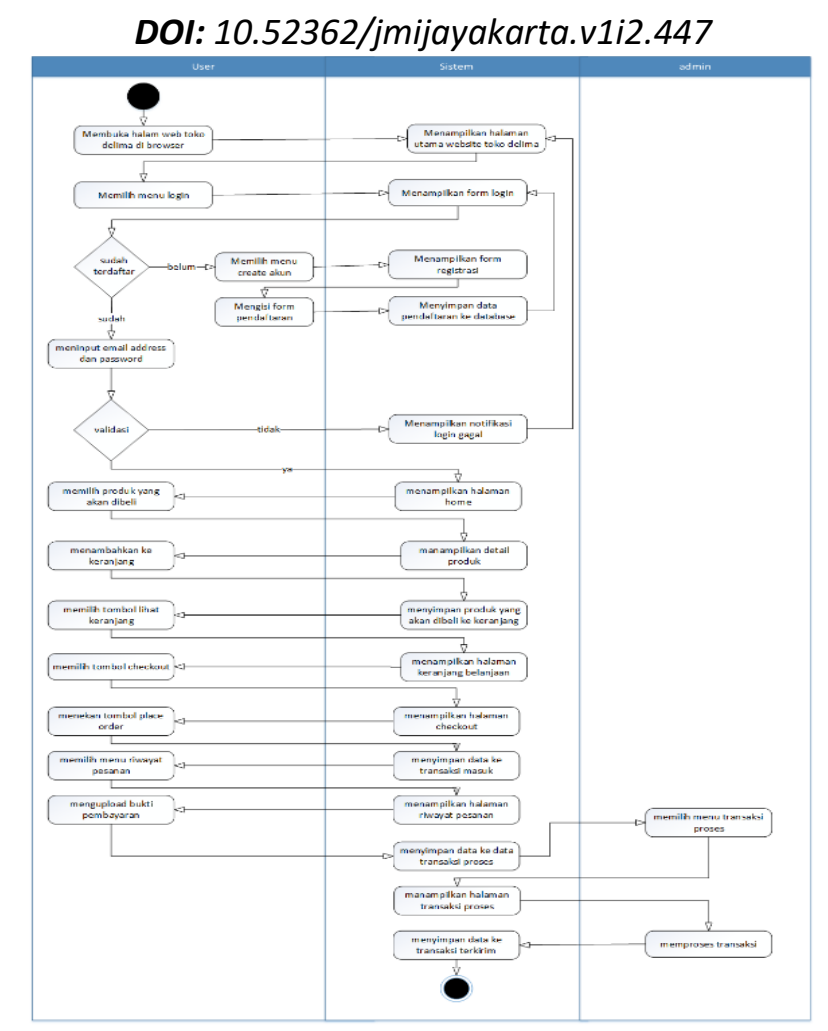

\section{Gambar 3. 3 Activity Diagram}

Activity diagram adalah gambaran urutan aktivitas dalam sistem yang dapat dilakukan oleh user dari awal hingga akhir sehingga dapat memberikan pemahaman secara keseluruhan.

Pada Gambar 3.3 dapat dijelaskan bahwasanya dimulai dari pelanggan datang ke Toko untuk melihat barang yang akan dibeli atau dipesan. Pemilik toko melayani pelanggan. Pelanggan melakukan pemesanan barang, Pemilik toko mengkonfirmasi pesanan dan setelah itu membuat nota, Pelanggan melakukan pembayaran dan pelanggan memerima barang yang dibeli.

\section{Analisis}

Analisis sistem dapat didefinisikan sebagai penguraian dari suatu sistem yang utuh ke dalam bagian komponennya dengan maksud untuk mengidentifikasi dan mengevaluasi kebutuhan yang diharapkan sehingga dapat diusulkan perbaikan.

\subsection{Analisis SWOT}

Analisis SWOT adalah teori yang digunakan untuk merencanakan sesuatu hal. SWOT terdiri dari Strenght atau kekuatan, Weakness atau kelemahan, Oppurtunity atau kesempatan, dan Threat atau ancaman. SWOT ini biasa digunakan untuk menganalisis suatu kondisi dimana akan dibuat sebuah rencana untuk melakukan suatu program kerja.

a. Strength / Kekuatan : Transaksi antara pembeli dan penjual dilakukan secara cepat, dan mudah.

b. Weakness / Kelemahan : Barang tidak bisa dipegang secara langsung, kadang barang tersebut tidak sesuai dengan yang kita inginkan / beda dengan yang ditampilkan. 
DOI: 10.52362/jmijayakarta.v1i2.447

c. Opportunity / Peluang : Dapat menghasilkan produk baru yang banyak diminati customer / permintaan dari customer, jika produk sesuai, bagus dan memuaskan konsumen otomatis akan laris terjual.

d. Threat / Ancaman : Dikhawatirkan adanya pembuatan Website palsu, persaingan harga, kualitas.

\section{Tabel 3. 1 Analisis SWOT}

\begin{tabular}{|c|c|c|}
\hline Faktor Eksternal & $\begin{array}{ll}\text { Strenght } \\
\text { 1. } & \text { Jaminan kualitas } \\
& \text { kepada konsumen } \\
\text { 2. } & \text { Perusahaan } \\
& \text { memiliki supplier } \\
\text { tetap } & \\
\text { 3. } & \text { Memiliki layanan } \\
\text { tambahan terhadap } \\
\text { konsumen }\end{array}$ & $\begin{array}{ll}\text { Weakness } \\
\text { 1. } & \text { Produk yang } \\
& \text { kurang } \\
& \text { bervariasi/unik } \\
\text { 2. } & \text { Kurangnya media } \\
& \text { pemasaran untuk } \\
\text { menarik pelanggan } & \text { Turnover } \\
\text { 3. } & \text { karyawan masih } \\
\text { tinggi }\end{array}$ \\
\hline \begin{tabular}{ll}
\multicolumn{2}{l}{ Opportunity } \\
1. & Kesempatan Perluasan \\
& area usaha dan ekspor \\
& perusahaan \\
2. & Perkembangan sistem
\end{tabular} & $\begin{array}{l}\text { Strategi SO } \\
\text { 1. S1-S2-S3: } \\
\text { Menciptakan } \\
\text { produk berkualitas } \\
\text { dan mengikuti tren } \\
\text { S2-O2: Menambah } \\
\text { wilayah produksi } \\
\text { dan cakupan } \\
\text { pemasaran }\end{array}$ & \begin{tabular}{|l} 
Strategi WO \\
1. \\
W1: Meningkatkan \\
variasi produk dan \\
segmentasi pasar \\
2. \\
W2-O2: \\
Memaksimalkan \\
penggunaan media \\
internet sebagai \\
sarana promosi
\end{tabular} \\
\hline $\begin{array}{l}\text { Threat } \\
\text { 1. Persaingan ketat } \\
\text { dengan industri } \\
\text { sejenis } \\
\text { 2. Ancaman produk } \\
\text { pengganti } \\
\text { 3. Biaya peralihan } \\
\text { konsumen kecil }\end{array}$ & $\begin{array}{l}\text { Strategi ST } \\
\text { 1. } \\
\text { S1-S4-T1-T2-T3: } \\
\text { Meningkatkan } \\
\text { kualitas pelayanan } \\
\text { dan hubungan } \\
\text { feedback dengan } \\
\text { konsumen }\end{array}$ & 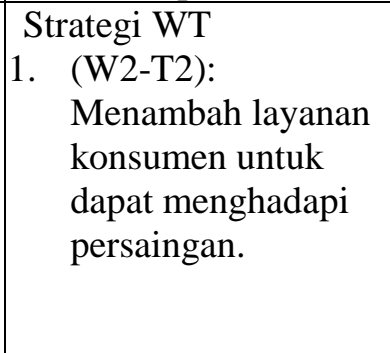 \\
\hline
\end{tabular}

\subsection{Analisis Kebutuhan Fungsional}

Analisis kebutuhan fungsional menggambarkan proses kegiatan yang akan diterapkan dalam sebuah sistem dan menjelaskan kebutuhan yang diperlukan sistem agar sistem dapat berjalan dengan baik sesuai kebutuhan. Pendekatan pemodelan analisis yang digunakan untuk perancangan Website penjualan ini adalah pemodelan prosedural. Pada aplikasi penjualan ini analisa kebutuhan fungsional meliputi:

Tabel 3. 2 Analisa kebutuhan fungsional

\begin{tabular}{|c|l|}
\hline \multicolumn{1}{|c|}{ Fitur } & \multicolumn{1}{|c|}{ Fungsi Fitur } \\
\hline Halaman Utama & $\begin{array}{l}\text { Menampilkan Kategori produk, produk yang dijual } \\
\text { dan menu login }\end{array}$ \\
\hline
\end{tabular}


DOI: 10.52362/jmijayakarta.v1i2.447

Tabel 3. 2 Analisa kebutuhan fungsional

\begin{tabular}{|l|l|}
\hline Menu Kategori & Menampilkan produk berdasrkan kategori barang \\
\hline Menu Login & Menampilkan form login \\
\hline Menu Keranjang & Menampilkan barang yang akan dibeli \\
\hline Menu riwayat pesanan & Menampilkan Riwayan pembelian barang \\
\hline Menu Rigister & Untuk mendaftarkan member baru/ pelanggan baru \\
\hline
\end{tabular}

\section{i. Analisisi Kebutuhan Non-Fungsional}

Di dalam membangun sistem, dibutuhkan perangkat keras dan perangkat lunak yang mendukung. Perangkat keras atau hardware merupakan salah satu hal yang penting karena tanpa hardware yang memenuhi syarat, program yang akan dibuat tidak akan dapat berjalan. Agar sistem dapat berjalan dengan baik, maka dibutuhkan perangkat keras yang sesuai dengan kebutuhan aplikasi. Uji coba yang dilakukan penulis dengan menggunakan Laptop.

\section{a. Analisis Perangkat Keras}

Untuk membangun sistem perangkat lunak, perangkat keras yang dipergunakan adalah :

Tabel 3. 3 Spesifikasi analisa perangkat keras

\begin{tabular}{|l|l|}
\hline Operation System & Windows 10 Pro 64-bit \\
\hline Prosessor : & Intel Core i3-2120 CPU @ 3.30GHz \\
\hline$R A M$ & $6144 \mathrm{MB}$ \\
\hline Internal Storage & $\mathbf{2 .}$ \\
\hline
\end{tabular}

\section{b. Spesifikasi Perangkat Lunak}

Perangkat lunak atau software merupakan hal yang terpenting dalam mendukung kinerja sebuah sistem. Perangkat lunak digunakan dalam sebuah sistem merupakan perintah-perintah yang diberikan kepada perangkat keras agar dapat saling berinteraksi diantara keduanya. Perangkat lunak yang dibutuhkan untuk membangun aplikasi penjualan ini adalah sebagai berikut:

1. Sublime Text

2. Chrome

3. XAMPP

\section{c. Analisa Kebutuhan User}

Selain dibutuhkannya perangkat lunak dan perangkat keras, user juga sangat dibutuhkan dalam penggunakaan sistem ini. Adapun spesifikasi user yang dibutuhkan yaitu mengerti dalam mengoperasikan computer.

\section{HASIL DAN PEMBAHASAN}

Pada tahap hasil dan pembahasan, penelitian telah menghasilkan Sistem Informasi Penjualan Material Bangunan Pada Toko Bangunan Delima 


\section{Hasil Tampilan}

DOI: 10.52362/jmijayakarta.v1i2.447

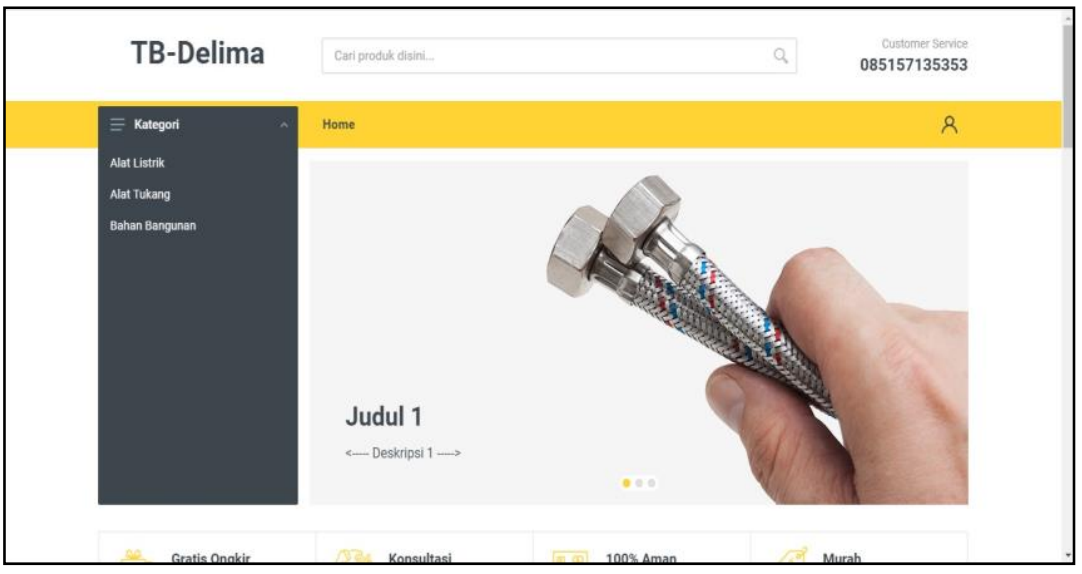

Gambar 4. 1 Halaman Utama

Halaman utama adalah tampilan yang akan muncul pada saat pertama kali user mengakses Website toko delima, pada halaman utama terdapat ketegori produk, produk yang akan dijual dan tombol login.

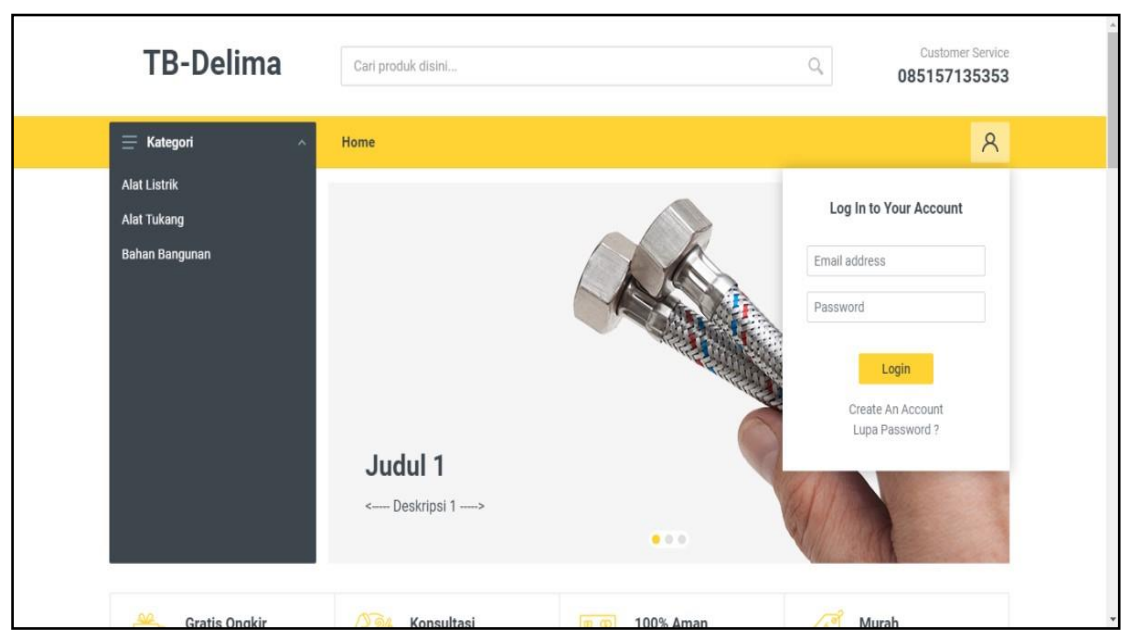

Gambar 4. 2 halaman form input login user

Pada tampilan halaman login pelanggan dapat menginput email address dan password untuk yang telah memiliki akun, untuk pelanggn yang belum memiliki akun dapat menekan tombol created an account

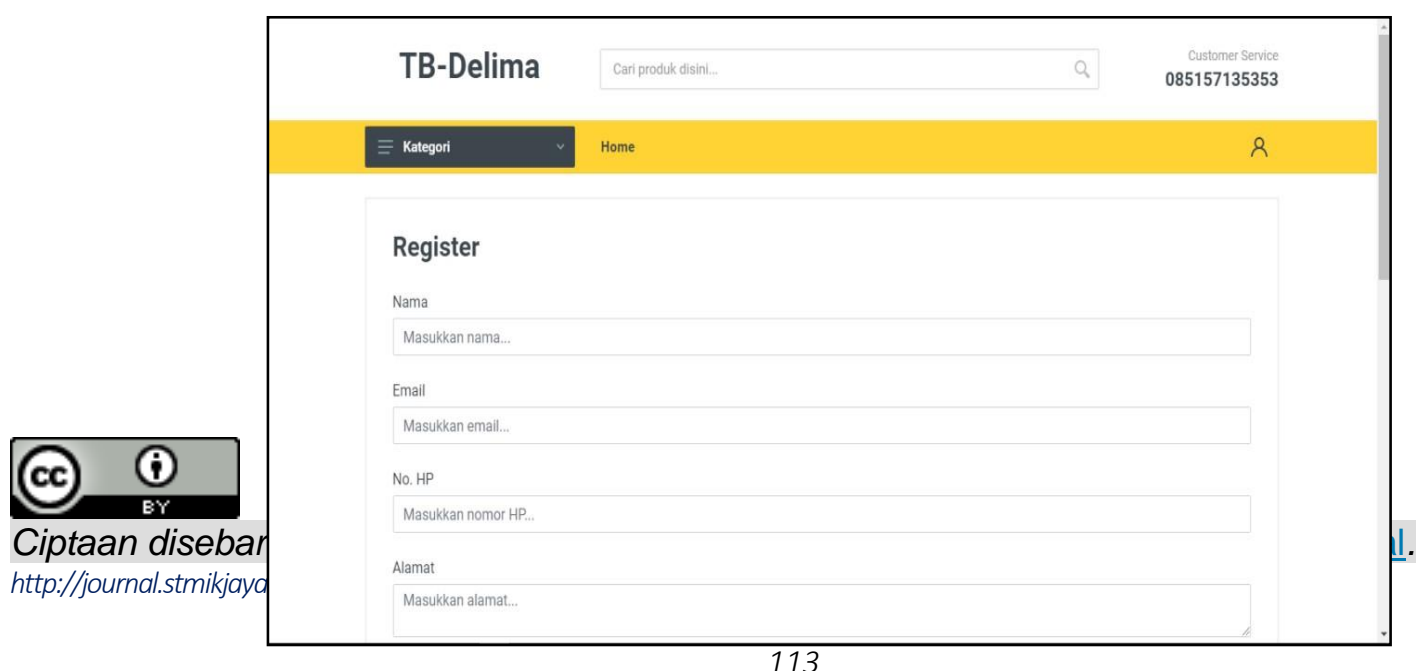


DOI: 10.52362/jmijayakarta.v1i2.447

\section{Gambar 4. 3 halaman form register}

Pada halaman register terdapat form yang harus diisi oleh pelanggan untuk mendaftar agar data pelangan tersebut dapat tersimpan di database.

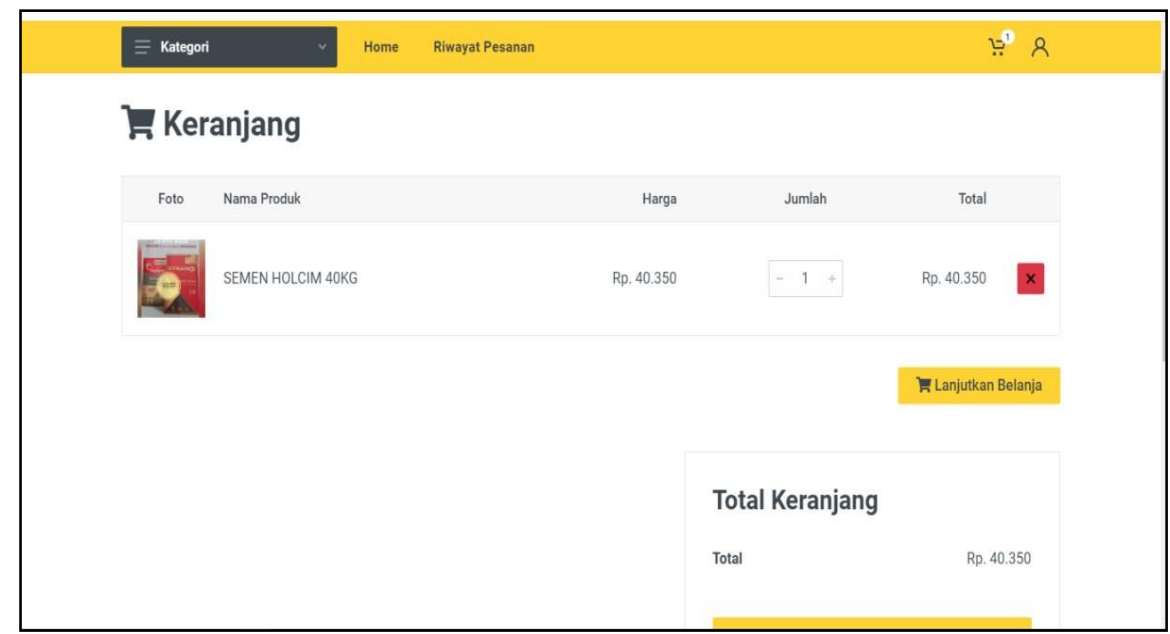

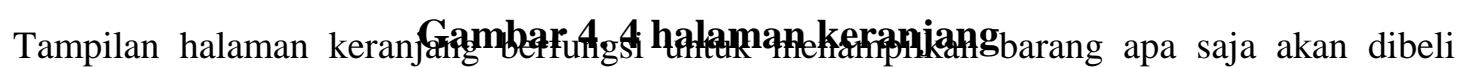
pelanggan di halaman tersebut terdapat detail barang yang akan dibeli mulai dari nama produk, gambar harga dan jumlah yang akan dibeli.

\section{Pengujian Sistem}

Kasus dan Hasil - hasil pengujian dibuat untuk membuktikan serta memperlihatkan bahwa aplikasi yang dikembangkan sudah sesuai dengan tujuan pengembangan dan mampu memenuhi kebutuhan pengguna. Selain itu kasus dan hasil pengujian ini juga memperlihatkan bahwa aplikasi sudah lulus dari kesalahan sesuai kasus pada tahap pengujian.

Tabel 5. 1 hasil pengujian black box

\begin{tabular}{|c|c|l|l|c|}
\hline \multirow{2}{*}{ No } & \multirow{2}{*}{$\begin{array}{c}\text { Kasus yang } \\
\text { akan diuji }\end{array}$} & \multicolumn{3}{|c|}{ Skenario dan Hasil Uji } \\
\cline { 3 - 5 } 1. & \multirow{4}{*}{$\begin{array}{c}\text { Menu } \\
\text { Masterisasi }\end{array}$} & $\begin{array}{l}\text { Memilih menu } \\
\text { profil toko }\end{array}$ & $\begin{array}{l}\text { Menampil yang diharpkan halaman profil } \\
\text { toko }\end{array}$ & Kesimpulan \\
\cline { 3 - 5 } & $\begin{array}{l}\text { Memilih menu } \\
\text { banner }\end{array}$ & $\begin{array}{l}\text { Menampilkan halaman } \\
\text { banner }\end{array}$ & Valid \\
\cline { 3 - 5 } & $\begin{array}{l}\text { Memilih menu } \\
\text { logo dan merek }\end{array}$ & $\begin{array}{l}\text { Menampilkan halaman logo } \\
\text { dan merek }\end{array}$ & Valid \\
\hline \multirow{4}{*}{2.} & $\begin{array}{l}\text { Memilih menu } \\
\text { distributor }\end{array}$ & $\begin{array}{l}\text { Menampilkan halaman } \\
\text { distributor }\end{array}$ & Valid \\
\cline { 3 - 5 } & \multirow{2}{*}{$\begin{array}{l}\text { Distributor } \\
\text { Menekan tombol } \\
\text { tambah distributor }\end{array}$} & $\begin{array}{l}\text { Menampilkan halaman form } \\
\text { tambah distributor }\end{array}$ & Valid \\
\cline { 3 - 5 } & & Menekan tombol & Menampilkan halaman edit & Valid \\
\hline
\end{tabular}


DOI: 10.52362/jmijayakarta.v1i2.447

Tabel 5.1 hasil pengujian black box

\begin{tabular}{|c|c|c|c|c|}
\hline & & edit distributor & distributor & \\
\hline \multirow{2}{*}{3.} & \multirow{2}{*}{$\begin{array}{c}\text { Menu } \\
\text { Pelanggan }\end{array}$} & $\begin{array}{l}\text { Memilih Menu } \\
\text { pelanggan }\end{array}$ & $\begin{array}{l}\text { Menampilkan halaman } \\
\text { pelanggan }\end{array}$ & Valid \\
\hline & & $\begin{array}{l}\text { Menekan Tombol } \\
\text { tambah pelanggan }\end{array}$ & $\begin{array}{l}\text { Menampilkan halaman } \\
\text { tambah pelanggan }\end{array}$ & Valid \\
\hline \multirow{4}{*}{4.} & \multirow{4}{*}{$\begin{array}{l}\text { Menu } \\
\text { Kategori }\end{array}$} & $\begin{array}{l}\text { Memilih menu } \\
\text { kategori }\end{array}$ & $\begin{array}{l}\text { Menampilkan halaman } \\
\text { kategori }\end{array}$ & Valid \\
\hline & & $\begin{array}{l}\text { Menekan tombol } \\
\text { tambah kategori }\end{array}$ & $\begin{array}{l}\text { Menampilkan halaman } \\
\text { tambah kategori }\end{array}$ & Valid \\
\hline & & $\begin{array}{l}\text { Menekan tombol } \\
\text { edit kategori }\end{array}$ & $\begin{array}{l}\text { Menampilkan halaman edit } \\
\text { kategori }\end{array}$ & Valid \\
\hline & & $\begin{array}{l}\text { Menekan tombol } \\
\text { hapus kategori }\end{array}$ & Menghapus kategori & Valid \\
\hline \multirow{4}{*}{5.} & \multirow{4}{*}{$\begin{array}{l}\text { Menu } \\
\text { Produk }\end{array}$} & $\begin{array}{l}\text { Memilih menu } \\
\text { produk }\end{array}$ & $\begin{array}{l}\text { Menampilkan halaman } \\
\text { produk }\end{array}$ & Valid \\
\hline & & $\begin{array}{l}\text { Menkan tombol } \\
\text { tambah produk }\end{array}$ & $\begin{array}{l}\text { Menampilkan halaman } \\
\text { tambah produk }\end{array}$ & Valid \\
\hline & & $\begin{array}{l}\text { Menkan tombol } \\
\text { edit produk }\end{array}$ & $\begin{array}{l}\text { Menampilkan halaman edit } \\
\text { produk }\end{array}$ & Valid \\
\hline & & $\begin{array}{l}\text { Menkan tombol } \\
\text { hapus produk }\end{array}$ & Menghapus produk & Valid \\
\hline \multirow{3}{*}{6.} & \multirow{3}{*}{$\begin{array}{c}\text { Menu } \\
\text { Inventori }\end{array}$} & $\begin{array}{l}\text { Memilih menu } \\
\text { inventori }\end{array}$ & $\begin{array}{l}\text { Menampilkan sub menu } \\
\text { inventori masuk dan } \\
\text { inventori keluar }\end{array}$ & Valid \\
\hline & & $\begin{array}{l}\text { Memilih sub menu } \\
\text { inventori masuk }\end{array}$ & $\begin{array}{l}\text { Menampilkan halaman } \\
\text { inventori masuk }\end{array}$ & Valid \\
\hline & & $\begin{array}{l}\text { Memilih sub menu } \\
\text { inventori keluar }\end{array}$ & $\begin{array}{l}\text { Menampilkan halaman } \\
\text { inventori keluar }\end{array}$ & Valid \\
\hline \multirow{2}{*}{7.} & \multirow{2}{*}{$\begin{array}{l}\text { Menu } \\
\text { Transaksi } \\
\text { Masuk }\end{array}$} & $\begin{array}{l}\text { Memilih menu } \\
\text { transaksi masuk }\end{array}$ & $\begin{array}{l}\text { Menampilkan halaman } \\
\text { transaksi masuk }\end{array}$ & Valid \\
\hline & & $\begin{array}{l}\text { Menekan tombol } \\
\text { view }\end{array}$ & $\begin{array}{l}\text { Menampilkan detail } \\
\text { transaksi masuk }\end{array}$ & Valid \\
\hline \multirow{2}{*}{8.} & \multirow{2}{*}{$\begin{array}{c}\text { Menu } \\
\text { Transaksi } \\
\text { Proses }\end{array}$} & $\begin{array}{l}\text { Memilih menu } \\
\text { transaksi proses }\end{array}$ & $\begin{array}{l}\text { Menampilkan halaman } \\
\text { transaksi proses }\end{array}$ & Valid \\
\hline & & $\begin{array}{l}\text { Menekan tombol } \\
\text { view }\end{array}$ & $\begin{array}{l}\text { Menampilkan detail } \\
\text { transaksi proses }\end{array}$ & Valid \\
\hline \multirow{2}{*}{9.} & \multirow{2}{*}{$\begin{array}{c}\text { Menu } \\
\text { Transaksi } \\
\text { kirim }\end{array}$} & $\begin{array}{l}\text { Memilih menu } \\
\text { transaksi kirim }\end{array}$ & $\begin{array}{l}\text { Menampilkan halaman } \\
\text { transaksi kirim }\end{array}$ & Valid \\
\hline & & $\begin{array}{l}\text { Menekan tombol } \\
\text { view }\end{array}$ & $\begin{array}{l}\text { Menampilkan detail } \\
\text { transaksi kirim }\end{array}$ & Valid \\
\hline 10. & $\begin{array}{c}\text { Menu } \\
\text { laporan } \\
\text { transaksi }\end{array}$ & $\begin{array}{l}\text { Memilih menu } \\
\text { laporan transaksi }\end{array}$ & $\begin{array}{l}\text { Menampilkan halaman } \\
\text { laporan transaksi }\end{array}$ & Valid \\
\hline 11 & Menu Akun & $\begin{array}{l}\text { Menmilih menu } \\
\text { akun }\end{array}$ & Menampilkan halaman akun & Valid \\
\hline
\end{tabular}




\section{KESIMPULAN}

DOI: 10.52362/jmijayakarta.v1i2.447

Informasi mengenai produk yang dijual pada Toko Bangunan Delima dapat diketahui oleh pelanggan maupun Masyarakat karena dapat diakses dimanapun dengan bantuan internet atau Mobile Android atau PC dan Laptop. Serta peningkatan efisiensi dan efektifitas proses penyampaian informasi produk tanpa harus terhalang oleh waktu dan tempat dibandingkan dengan system yang lama atau masih bersifat manual yang kurang efektif dan efisien karena masih bersifat manual.

Aplikasi ini, dapat membantu perusahaan dalam meningkatkan pelayanan dan penjualan di berbagai wilayah baik dalam kota maupun luar kota

\section{REFERENSI}

[1] Anggraeni,E.Y. (2017). Pengantar Sistem Informasi (E. RISANTO (ed.)). CV.ANDI OFFSET.

[2] Adiguna, A. R., Saputra Chandra, M., \& Pradana, F. (2018). Analisis dan Perancangan Sistem Informasi Manajemen Gudang pada PT Mitra Pinasthika Mulia Surabaya. Jurnal Pengembangan Teknologi Informasi Dan Ilmu Komputer, 2(2), 612-621.

[3] Andalia, F., \& Setiawan, E. B. (2015). Pengembangan Sistem Informasi Pengolahan Data Pencari Kerja Pada Dinas Sosial Dan Tenaga Kerja Kota Padang. Komputa : Jurnal Ilmiah Komputer Dan Informatika, 4(2), 93-97. https://doi.org/10.34010/komputa.v4i2.2431

[4] R. M. Barts, "The Stub Loaded Helix: A Reduced Size Helical Antenna," Doctoral Dissertation, 2003. [Online]. Available: http://hdl.handle.net/10919/29728.

[5] Prasetyo, A., \& Susanti, R. (2016). Sistem Informasi Penjualan Berbasis Web Pada PT. Cahaya Sejahtera Sentosa Blitar. Jurnal Ilmiah Teknologi Informasi Asia, 10(2), 1-16.

[6] Ramadhan, T. S. (2008). Perancangan Sistem Informasi Persediaan Barang Berbasis Web Pada Program Non Reguler Fakultas Sains Dan Teknologi UIN Syarif Hidayatullah Jakarta. 1-211.

[7] Ratumurun, S., Kristen, U., \& Maluku, I. (2005). Permintaan Dana Untuk Kegiatan Pembiayaan Proyek Pada Pt. Tirsula Inovasi Ambon. 217-226.

[8] Syifani, D., \& Dores, A. (2018). Aplikasi Sistem Rekam Medis di Puskesmas Kelurahan Gunung. Jurnal Sistem Informasi, Teknologi Informatika Dan Komputer, 9(1), 22-31.

[9] Benni Triyono, Sri Purwanti, Verdi Yasin (2017) "Rekayasa Perangkat Lunak Sistem Informasi Pengiriman Dan Penerimaan Surat Atau Paket Berbasis Web", Journal of Information System, Applied, Management, Accounting and Research, e-ISSN: 2598-8719. p-ISSN: 2598-8700.Vol.1 No.1 (30 Desember 2017) p46-53 http://journal.stmikjayakarta.ac.id/index.php/jisamar/article/view/12

[10] Verdi Yasin, Muhammad Zarlis, Mahyuddin K.M. Nasution (2018) "Filsafat Logika Dan Ontologi Ilmu Komputer", Journal of Information System, Applied, Management, Accounting and Research, e-ISSN: 2598-8719. p-ISSN: 2598-8700.Vol.2 No.2 (19 Juni 2018) p68-75 http://journal.stmikjayakarta.ac.id/index.php/jisamar/article/view/39

[11] Julinda Maya Paramudita, Verdi Yasin (2019) "Perancangan Aplikasi Sistem Penyewaan Alat Berat “, Journal of Information System, Applied, Management, Accounting and Research, e-ISSN: 2598-8719. p-ISSN: 2598-8700.Vol.3 No.1 (20 Februari 2019) p23-29 http://journal.stmikjayakarta.ac.id/index.php/jisamar/article/view/73

[12] Muryan Awaludin, Verdi Yasin (2020) “Application Of Oriented Fast And Rotated Brief (Orb) And Bruteforce Hamming In Library Opencv For Classification Of Plants", Journal of Information System, Applied, Management, Accounting and Research, e-ISSN: 25988719. p-ISSN: 2598-8700.Vol.4 No.3 (14 Agustus 2020) p51-59 http://journal.stmikjayakarta.ac.id/index.php/jisamar/article/view/247

[13] Ifan Junaedi, Dimas Abdillah, Verdi Yasin (2020) “Analisis Perancangan Dan Pembangunan Aplikasi Business Intelligence Penerimaan Negara Bukan Pajak Kementerian Keuangan RI", Journal of Information System, Applied, Management, Accounting and Research, e-ISSN: 2598-8719. p-ISSN: 2598-8700.Vol.4 No.3 (14 Agustus 2020) p88-101 http://journal.stmikjayakarta.ac.id/index.php/jisamar/article/view/249 